\title{
Analysis of the Working Environment with a Focus on Laboratory Lightning
}

\author{
Gabriela Dancáková ${ }^{1, *}$, Viktória Holodáková ${ }^{1}$, Teodor Tóth ${ }^{1}$, Samuel Lancoš ${ }^{1}$, Radovan Hudák ${ }^{1}$ \\ Faculty of Mechanical Engineering, Department of Biomedical Engineering and Measurement, Technical University of Košice, Letná 9, 04200 \\ Košice, Slovakia
}

Abstract: The aim of the publication is ergonomic analysis and evaluation of lighting physical parameters for selected laboratory of the Faculty of Mechanical Engineering at Technical University of Košice. The reason for the analysis is planned modernization of the laboratory and the identification of possible environmental risk factors for their optimization during the modernization process. The results of the measurements were assessed regarding the valid standards. In case of unsatisfactory conditions, their optimization was proposed, meeting the ergonomic, safety and hygienic parameters according to the valid legislation.

Keywords: ergonomics 1; working environment 2; ergonomic analysis 3; lighting 4

\section{Introduction}

Health is an integral part of human life. It is influenced by various factors. One of these factors is the influence of the environmental conditions in which the individual is located. It is not just about the environment, but also the working environment. The issue of the working environment and its impact on the human body is addressed by a scientific discipline - Ergonomics of the working environment. The main benefits of ergonomics include reducing the incidence of occupational diseases, improving work efficiency and, last but not least, improving the quality of work [1].

That is why ergonomics is an integral part of the work environment, in order to meet the needs of the worker who performs the work [2].

Occupational hygiene is focused on the conditions present in the work environment. These conditions include microclimate, noise, vibration, lighting and polluted air. These factors directly affect work, performance and, last but not least, overall human health. The aim of occupational hygiene is to ensure prevention against occupational diseases [3].

Universities in the Slovak Republic are gradually approaching the modernization of their laboratories due to their obsolescence (room equipment, new focus, etc.) or to reduce their energy intensity. One of the key parameters is the replacement of light sources, because the current luminaires can provide required performance with lower energy consumption.

As part of the renewal of the laboratories, a comprehensive modernization of the selected laboratory is planned, including the modification of its layout, electricity distribution and lighting sources, also at the Faculty of Mechanical Engineering of the Technical University in Košice.

The publication focuses on the physical factor of environmental lighting, which is one of the risk factors in the work environment. This can significantly affect a person's visual system and consequently his overall health. The extent of the effect on a person depends on its intensity, length and frequency of action [3]. 
Lighting intensity and its physical factors affects work productivity and safety at work. Prevents eye damage and reduces worker fatigue. The required lighting intensity is based on the type of activity performed, the average age of employees, the distance of the monitored object and need for detailed focus. The intensity of lighting is also affected by the colour of the surrounding environment in which the worker / student is located. The sum of all the above factors and criteria creates the basis for the creation of an optimal lighting environment for the worker (Table 1). Human vision performs its functions in such an adapted optimal environment. A person feels good in such a modified environment, which is also reflected in his psyche. This psychophysiological condition is called visual well-being [3][9][10].

The article analyzes the current state of the laboratory in terms of its lighting and determining the changes after its modernization.

\section{Characteristics of the laboratory and descripti- on of performed activity}

The selected laboratory serves as a classroom for full-time students in I. and II. degree of study. The floor plan of the room has the dimensions 5850 $\times 5850 \mathrm{~mm}$, while the height at the lowest point of the room reaches $3300 \mathrm{~mm}$ and at the highest point $4370 \mathrm{~mm}$ (Figure 1). On its eastern side there are two lighting openings (windows) measuring $1940 \times 2380 \mathrm{~mm}$, at a height of bottom part of window $1980 \mathrm{~mm}$ above the floor. They include vertical blinds. The ceiling is graduated, the lower part is $3300 \mathrm{~mm}$ high and the higher $4300 \mathrm{~mm}$ from the floor of the room. The artificial lighting of the laboratory consists of linear fluorescent lighting ( 12 bodies with 2 tubes) with a total power of 864 W, 8 of which are located on the lower and 4 on the higher ceiling.

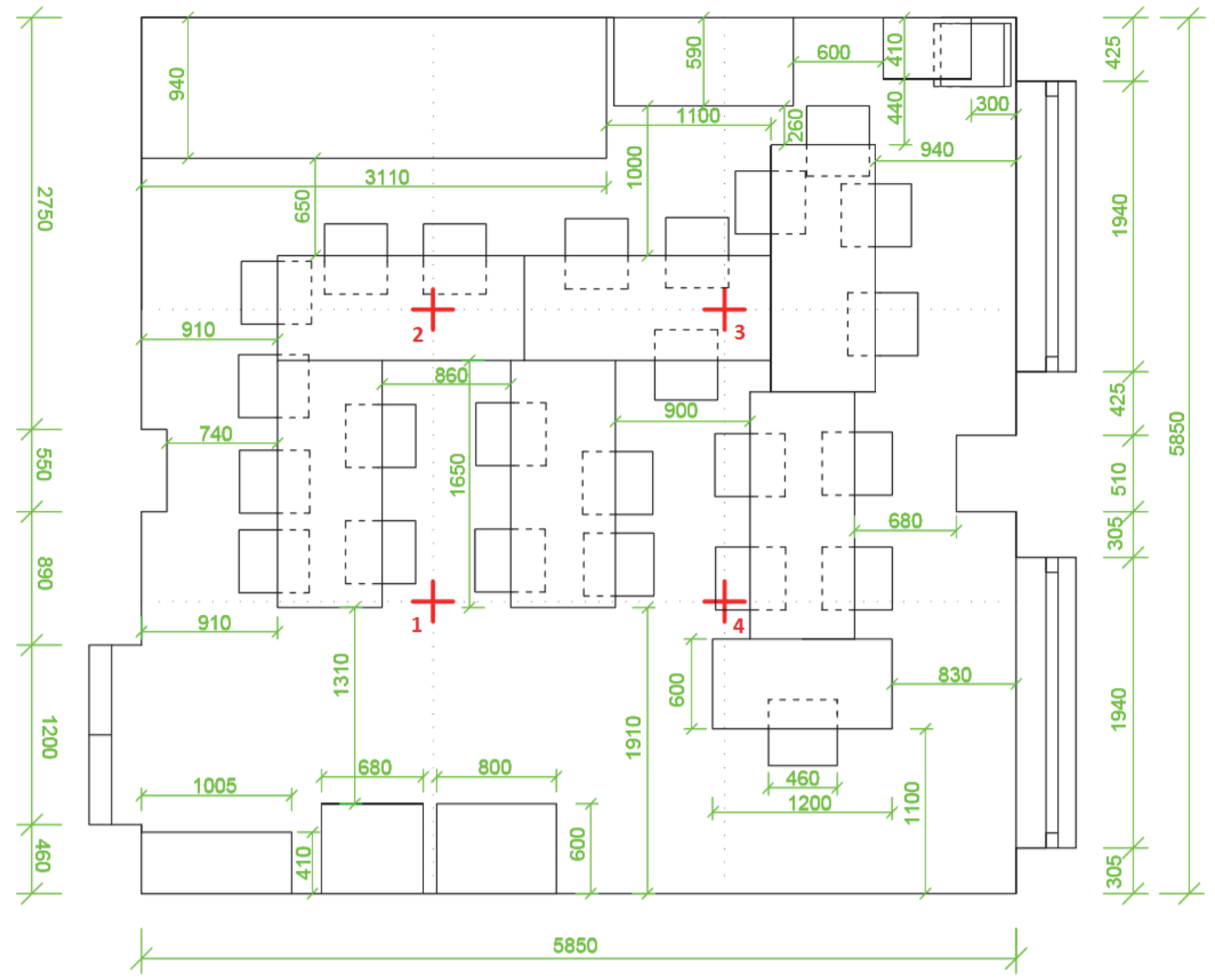

Figure 1: Laboratory floor plan, red intersections indicate the measurement points (1 - 4) 
There are 8 workbenches and 26 chairs in the laboratory.

All measurements were performed using a Fluke $416 \mathrm{D}$ laser distance meter with a range of $50 \mathrm{~mm}$ $6000 \mathrm{~mm}$. Measuring accuracy was $\pm 15 \mathrm{~mm}$.

Activities performed in the laboratory include reading, writing, performing laboratory exercises and presenting semester works.

\subsection{General lighting conditions}

From the source point of view, lighting is divided into three categories: daylighting, artificial and combined lighting [3].

Table 1: Minimum and average values of the daylight factor according to individual classes of visual activity [4]

\begin{tabular}{|l|l|l|l|l|}
\hline \multirow{2}{*}{$\begin{array}{l}\text { Visual } \\
\text { activity } \\
\text { class }\end{array}$} & \multirow{2}{*}{$\begin{array}{l}\text { Visual } \\
\text { activity }\end{array}$} & \multirow{2}{*}{$\begin{array}{l}\text { Example of visual } \\
\text { activity }\end{array}$} & \multicolumn{2}{|l|}{ Daylight factor } \\
\cline { 3 - 5 } & $\begin{array}{l}\text { Extremely } \\
\text { accurate }\end{array}$ & $\begin{array}{l}\text { Dmin } \\
\text { The most accurate } \\
\text { visual activities with } \\
\text { limited use of magni- } \\
\text { fication; requirement } \\
\text { to eliminate the } \\
\text { resolution errors }\end{array}$ & 3.5 & $\begin{array}{l}\text { Dmax } \\
{[\%]}\end{array}$ \\
\hline II & Very accurate & $\begin{array}{l}\text { Very precise visual } \\
\text { activities; limited visual } \\
\text { control }\end{array}$ & 2.5 & 7 \\
\hline III & Accurate & $\begin{array}{l}\text { Precise visual activities; } \\
\text { precise production and } \\
\text { control }\end{array}$ & 2.0 & 6 \\
\hline IV & $\begin{array}{l}\text { Moderately } \\
\text { accurate }\end{array}$ & $\begin{array}{l}\text { Moderately accurate } \\
\text { visual activities }\end{array}$ & 1.5 & 5 \\
\hline
\end{tabular}

\section{Measurement methods}

The environment and the sky during the measurement meet the conditions for measuring daylight according to standards (STN 73 0580-1 Daylighting of buildings. Part 1: Basic requirements) [5].

Adequate conditions for our measurement occurred within two days. On both days, it was measured between 09:00 in the morning and 15:00 in the afternoon. The measurement was repeated at 90 minutes intervals. The scanning height was 0.85 $\mathrm{m}$ above the floor.

A Foot Candle Meter, model 401027 (Extech, Boston, Massachusetts, USA) was used to measure illumination. The meter measures in Foot Candles [FC] units with a measurement accuracy of $\pm 5 \%$. It provides 2 options for measuring the "A" range (0 -
199.9 FC) with a sensitivity of $0.1 \mathrm{Fc}$ and the "B" range (200 - 1999 FC) with a sensitivity of 1 Fc [6].

Range "A" was used for indoor measurements and range "B" for outdoor measurements.

The measured values were converted to lux according to the standard $1 \mathrm{FC}=10.736911 \times$ [8].

\subsection{Daylight measurement}

The following conditions were ensured when measuring on a clear sunny day [7]:

\section{- Dark terrain (without rain and snow)}

- With the help of vertical blinds, the direct impact of sunlight was eliminated during a sunny day; if direct sunlight stopped penetrating directly into the room, the blinds were reopened

- Artificial lighting sources were not active during this measurement

The following conditions were observed during the measurement of daylight in cloudy weather [7]:

- Darkterrain

- Vertical blinds in the position expected during a normal cloudy day

- Artificial lighting deactivated

according to the formula:

$$
D=\frac{E_{\text {inside }}}{E_{\text {outside }}} \cdot 100[\%]
$$

where: D - daylight factor, Einside. - light intensity in the room, Eoutside. - intensity of external light.

Daylight factors were calculated from each measured data.

As the measuring range of the Foot Candle Meter was not sufficient, the reference value of the intensity of outdoor daylight in a clear sky had to be used, in this case $100000 \mathrm{~lx}$ [3].

The measured value of outdoor lighting under cloudy skies after recalculation to lux reached the value of 13648.65 Ix.

The resulting values of the daylight factor were determined as the average resultants of the daylight from the arithmetic averages of the resultants at individual points at a certain time with normalized values.

\subsection{Measurement of artificial lighting}

Measurements for artificial lighting were performed in the evening and at designated points, at 20:00, 09.04.2019 at a height of $0.85 \mathrm{~m}$ above the floor.

The following conditions were provided prior to the measurement itself [7]:

- Avoidance of the influence of other light sources (daylight, lighting from sources of adjacent spaces)

- Stabilization of the luminous flux of artificial lighting sources 
(measurement took place approximately 10 minutes after illumination).

The result of the measurement is the average value of the intensity of artificial lighting from the measured values at the designated points. These values were then compared with the normalized values.

\subsection{Combined lighting measurement}

The combined lighting was measured along with daylight, in cloudy weather at the same points and time range. First, the daylight values were measured, then the resulting average values of the daylight factor were calculated from them. After stabilizing the artificial lighting sources, the values of the combined lighting were measured.

The measurement result for combined illumination is the average value of the combined illumination from the arithmetic averages of the measured data at certain points and at a certain time. These values were then compared with the normalized values.

\section{Results}

From the measured values it can be observed (Table 2), that the highest measured values of daylight intensity and the calculated partial average value of daylight factor were measured at 9:00 a.m., despite the prevention of direct sunlight over the entire area of lighting openings oriented to the east by vertical blinds. In contrast, the values measured at 10:30 a.m. with constant blocking of direct penetration of sunlight but not through the area of the lighting openings show a significant decrease in the values of light intensity and partial average value of the daylight factor due to the earth's movement against the Sun. From 12:00 to 15:00 at the afternoon, the laboratory was not exposed to direct sunlight. For this reason, the measurements were performed with the vertical blinds open. After comparing the measured values from 10:30 a.m. and 12:00, an increase in values at 12:00 can be observed, precisely due to the opening of vertical blinds.

Other measured and calculated values decrease over time. It can also be noted that the values measured in points 3 and 4 were always higher than the values measured in points 1 and 2 . The reason for these differences is the position, as they are closer to the lighting openings and the light does not fall at a sharper angle.

When evaluating the lighting according to the
Decree of the Ministry of the Slovak Republic [1 1] on details and requirements for lighting at work, it was proved that the view of the seated person through the lighting openings is not directed approximately horizontally to the exterior. For this reason, the windows in the laboratory are characterized as upper lighting openings and further evaluation was performed according to the relevant standards for upper lighting openings (Figure 2).

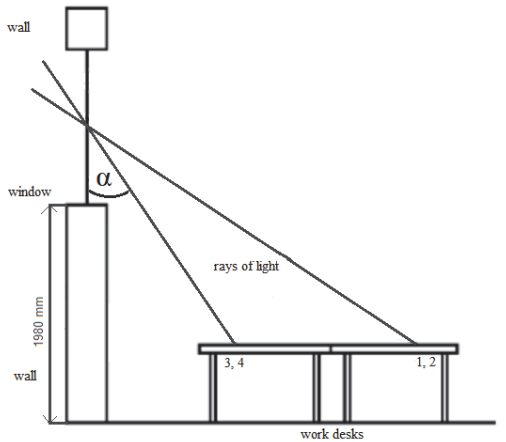

Figure 2: Representation of upper lighting openings

In terms of visual activity classes, the laboratory belongs to medium-precise, i.e. class IV.

The table below (Table 3) shows the listed and compared calculated values, also the standardized values of daylight factors according to the Decree of the Ministry of Health of the Slovak Republic [11] and according to the division of visual activity classes. In both cases, the measured values are insufficient.

Table 2: Measured and calculated values of daylight in clear sky

\begin{tabular}{|l|l|l|l|l|l|}
\hline \multirow{4}{*}{ Measuring point } & \multicolumn{5}{|l|}{ Measured values of daylight [lx] } \\
\cline { 2 - 6 } & $9: 00$ & $10: 30$ & $12: 00$ & $13: 30$ & $15: 00$ \\
\cline { 2 - 6 } & \multicolumn{4}{|l|}{ Vertical blinds } \\
\cline { 2 - 6 } & \multicolumn{4}{l|}{ closed } & \multicolumn{3}{l|}{ opened } \\
\hline 1 & 485.45 & 142.08 & 219.58 & 160.38 & 149.62 \\
\hline 2 & 503.75 & 139.93 & 190.52 & 164.69 & 150.69 \\
\hline 3 & 1057.02 & 319.69 & 300.31 & 223.89 & 220.66 \\
\hline 4 & 996.74 & 282.01 & 345.52 & 248.65 & 240.04 \\
\hline $\begin{array}{l}\text { Partial average values } \\
\text { D [\%] }\end{array}$ & 0.76 & 0.22 & 0.26 & 0.20 & 0.19 \\
\hline $\begin{array}{l}\text { The resulting average } \\
\text { value Dm [\%] }\end{array}$ & & & & & 0.33 \\
\hline *the lowest partial value & & & & \\
\hline
\end{tabular}


Table 3: Measured and calculated values of daylight in clear sky

\begin{tabular}{|c|c|c|c|c|}
\hline \multirow[t]{3}{*}{ Comparison point of view } & \multicolumn{4}{|c|}{$\begin{array}{l}\text { Comparison of normalized and calculated } \\
\text { values of daylight factors in clear skies }\end{array}$} \\
\hline & \multicolumn{2}{|c|}{ Standard value } & \multicolumn{2}{|c|}{ Calculated value } \\
\hline & $\begin{array}{l}\text { Dmin } \\
{[\%]}\end{array}$ & $\begin{array}{l}\mathrm{Dm} \\
{[\%]}\end{array}$ & $\begin{array}{l}\text { Dmin } \\
{[\%]}\end{array}$ & Dm [\%] \\
\hline $\begin{array}{l}\text { Decree of the Ministry of } \\
\text { Health of the Slovak Republic } \\
{[10]}\end{array}$ & 1.5 & 3 & 0.19 & 0.33 \\
\hline Class IV visual activity & 1.5 & 5 & & \\
\hline
\end{tabular}

The table (Table 4) shows the measured values of daylight and combined lighting in the laboratory under cloudy skies. Here, too, the values measured in cloudy weather are higher in points 3 and 4 than in points 1 and 2 . The highest measured values and the calculated partial average daylight factor were at 9:00 in the morning and the lowest at 15:00 in the afternoon. All partial average values of daylight factors are insufficient, which means that the resulting average value of daylight factor is also insufficient, daylight is unsatisfactory during the cloudy sky (Table 5). However, in terms of the conditions intended for combined lighting, the calculated minimum value of the daylight factor, Dmin $=0.57 \%$, did not fall below the required range of values, 0.5 $<$ Dmin $<1.5 \%$, which, however, cannot be said of the resulting average value $\mathrm{Dm}=0.63 \%$, which does not fall within the standardized range 1,5\% < Dmin $<3 \%$. Despite this unsatisfactory value, an evaluation of the combined lighting was performed for the needs of the work. The highest measured values were also recorded in daylight at 9:00 AM, but not in points 3 and 4, but in points 1 and 2. The reason is the placement of eight sources of artificial lighting directly above points 1 and 2 at a lower height than the location four sources of artificial lighting above points 3 and 4, which are located above due to the increasement of the ceiling. The lowest values were measured at 15:00 in the afternoon. The partial average values of the combined lighting in the time interval 9:00 - 13:30 are sufficient for the students work in the laboratory. However, this does not apply to the average value measured at 15:00 in the afternoon. The resulting average value of the combined lighting is nevertheless in accordance with the standard value (Table 5). The standard value for artificial lighting with combined is $500 \mathrm{~lx}$.

Table 5: Partial and final average values of daylight and combined lighting under cloudy skies

\begin{tabular}{|l|l|l|}
\hline Measurement time & $\begin{array}{l}\text { Partial average } \\
\text { values of the daylight } \\
\text { factor D [\%] }\end{array}$ & $\begin{array}{l}\text { Partial average values } \\
\text { of combined lighting } \\
\text { Em [lx] }\end{array}$ \\
\hline $9: 00$ & 0.70 & 570.23 \\
\hline $10: 30$ & 0.67 & 519.99 \\
\hline $12: 00$ & 0.63 & 509.89 \\
\hline $13: 30$ & 0.60 & 502.44 \\
\hline $15: 00$ & 0.57 & 478.22 \\
\hline $\begin{array}{l}\text { The resulting average } \\
\text { value Dm [\%] }\end{array}$ & 0.63 & - \\
\hline $\begin{array}{l}\text { The resulting average } \\
\text { value Em [Ix] }\end{array}$ & - & 516.15 \\
\hline * lowest partial values & satisfactory value & unsatisfactory value \\
\hline
\end{tabular}

The total artificial lighting calculated as the average of the measured values is insufficient. Its value differs from the standard value by less than 100 lux (Table 6). As in the previous case, the values measured in points 1 and 2 are higher than the values measured in points 3 and 4 for the same reason as given for the measured values of the combined lighting.

\section{Discussion}

As the above results show, insufficient lighting results in reduced visual well-being, which results in visual impairment. In the laboratory, it is important

Table 4: Comparison of daylight measurement results in cloudy skies

\begin{tabular}{|c|c|c|c|c|c|c|c|c|c|c|}
\hline \multirow{3}{*}{$\begin{array}{l}\text { Measuring point } \\
1\end{array}$} & \multicolumn{10}{|c|}{ Measured values of daylight and combined lighting under cloudy skies [lx] } \\
\hline & \multicolumn{2}{|l|}{ 9:00 } & \multicolumn{2}{|l|}{$10: 30$} & \multicolumn{2}{|l|}{ 12:00 } & \multicolumn{2}{|l|}{ 13:30 } & \multicolumn{2}{|l|}{ 15:00 } \\
\hline & 70.28 & 620.00 & 68.37 & 616.45 & 55.43 & 600.77 & 53.00 & 599.09 & 49.87 & 557.07 \\
\hline 2 & 73.19 & 536.04 & 70.12 & 530.69 & 67.33 & 519.50 & 65.47 & 517.34 & 60.09 & 500.11 \\
\hline 3 & 118.4 & 560.84 & 113.22 & 466.37 & 110.96 & 460.08 & 105.02 & 449.71 & 99.58 & 415.23 \\
\hline 4 & 119.48 & 564.03 & 113.29 & 466.4 & 108.73 & 459.21 & 103.98 & 443.62 & 102.77 & 440.47 \\
\hline
\end{tabular}


Table 6: Comparison of artificial lighting measurement results with a standard value

\begin{tabular}{|c|c|c|}
\hline Measuring point & $\begin{array}{l}\text { Measured values of artificial } \\
\text { lighting Em [lx] }\end{array}$ & $\begin{array}{l}\text { Standard } \\
\text { value Em }[\mathrm{Ix}]\end{array}$ \\
\hline 1 & 444.55 & \multirow[t]{5}{*}{500} \\
\hline 2 & 444.39 & \\
\hline 3 & 357.36 & \\
\hline 4 & 356.91 & \\
\hline $\begin{array}{l}\text { Resulting average value } \\
\text { Em [lx] }\end{array}$ & 400.80 & \\
\hline
\end{tabular}

to emphasize the correct placement of worktables and chairs. It is clear from the floor plan of the building that some desks are situated so that the worker / student is placed with his back to the window and thus creates his own shadow on the work surface. The solution to this problem is to properly arrange the workbenches and chairs so that the daylight coming into the room falls on each workstation from the side.

Despite unsatisfactory daylight conditions, this parameter can be adjusted by a combination of daylight and artificial lighting and thus by combined lighting. The intensity of such lighting meets the conditions for general combined lighting.

The values of the general artificial lighting showed the same unsatisfactory values as in the case of daylight. For this reason, it is not recommended to work in this laboratory in the evening. However, as the laboratory is not used in the evening, these results have no effect on workers.

Measurements taken in early April raise the issue of working days during the winter, when it gets dark earlier. The solution could be local lighting for each workplace.

The laboratory can be used under simultaneous lighting as a computer room where the required value is at the level of $300 \mathrm{~lx}$, and thus is suitable for both combined and artificial room lighting.

\section{Conclusions}

The ergonomic design of workplaces and jobs is closely linked to the health of working people. If the working conditions are set to suit their physical, physiological and mental requirements, it can be stated that such a working environment is optimal for the workers.
It is clear from the results that the laboratory does not meet the required ergonomic criteria to ensure optimal conditions.

Daylight is insufficient not only in cloudy skies, but also on a sunny day. Artificial lighting also achieves insufficient values.

In the case of the modernization of the laboratory, it is necessary to solve the replacement of lighting fixtures and increase their light output either by a larger number of fixtures, but with a higher output of individual sources.

\section{Acknowledgments}

This research was supported by projects VEGA 1/0179/19 Development and construction of low-cost modular prostheses of upper limbs manufactured by additive technologies; KEGA 040TUKE-4/2019 Use of digitization technologies for educational process support in the field of prosthetics and orthotics and KEGA 041TUKE-4/2019 Design of progress algorithms in additive technologies for the educational process in biomedical engineering.

\section{References and Notes}

[1] PANDVE, H. T. (2017). Historical Milestones of Ergonomics: From Ancient Human to Modern Human. Journal of Ergonomics, 7, 4, 169.

[2] MAREK, J., SKŘEHOT, P. (2009). Základy aplikované ergonomie. VÚBP, Praha, 1. editon., 118.

[3] KOVÁČ, J., SZOMBATHYOVÁ, E. (2010). Ergonómia. Technická univerzita v Košiciach, Strojnícka fakulta, Košice, 1. edition, 122.

[4] ŠPES, M. (2016). Denné osvetlenie vnútorných pracovných priestorov. Posterus: Portál pre odborné publikovanie, 9, 10, 1-10.

[5] HANKER, J. a kol. (1978). Ergonómia v priemysle. ALFA, Bratislava, 1. editon, 383.

[6] Extech. Pocket-Size Foot Candle Light, from http://www.extech. com/products/401027

[7] VESTNÍK, M. Z. SR amount 27-49 of 29 November 2013. Decree of the Ministry of Health of the Slovak Republic of 18 November 2013 no. S08305-OL-2013. Bratislava: V OBZOR, 2013.

[8] UnitConverters.net. Convert Foot-candle to Lux, from https:// www.unitconverters.net/illumination/foot-candle-to-lux.htm

[9] TREBUŇOVÁ, M., ŽIVČÁK, J. (2015). Biofyzika pre biomedicínske inžinierstvo, Edícia vedeckej a odbornej literatúry, strojnícka fakulta, Grafotlač s.r.o. Prešov, 1. edition, 102 - 105.

[10] TREBUŇOVÁ, M., ŽIVČÁK, J. (2017). Zbierka úloh z biofyziky pre biomedicínske inžinierstvo, Edícia vedeckej a odbornej literatúry, strojnícka fakulta, Grafotlač s.r.o. Prešov, 1. edition, 95 - 96.

[11] Decree no. 541/2007 Coll. Of the Ministry of Health of the Slovak Republic of 28 November 2007 on details of requirements for lighting at work (amended by Decree No. 206/2011 Coll.). 